\title{
Amyloidosis and Spontaneous Liver Bleeding: A Case Report and Literature Review
}

\author{
Biying Huang*, Ioannis Gkekas, Ernesto Sparellid
}

Department of Surgery, Karolinska Institute, Stockholm, Sweden

\section{Email address:}

biying.huang@sll.se (Biying Huang)

${ }^{*}$ Corresponding author

\section{To cite this article:}

Biying Huang, Ioannis Gkekas, Ernesto Sparellid. Amyloidosis and Spontaneous Liver Bleeding: A Case Report and Literature Review. Journal of Surgery. Vol. 7, No. 4, 2019, pp. 96-100. doi: 10.11648/j.js.20190704.12

Received: May 6, 2019; Accepted: June 5, 2019; Published: July 11, 2019

\begin{abstract}
Liver rupture with severe liver bleeding in patients with amyloidosis is an unusual but generally difficult to deal with and potentially fatal complication in these patients. Even patients with known manifestations to the lever can present with acute lever bleeding. Here we present a case report of a 62-year-old male with systemic immunoglobulin light chain (AL) amyloidosis, known manifestations to the lever and spontaneous liver bleeding which was treated conservatively without the need of surgical intervention. The etiology, panorama of clinical manifestations of hepatic amyloidosis and the management of liver bleeding in association with this unusual disease are reviewed. 18 cases of hepatic rupture and haemorrhage in association with amyloidosis in previously published cases are summarized. The choice of management should be individualized and the patient's hemodynamic status and extent of liver bleeding are important factors to be taken into consideration. In all patients it is crucial to exclude underlying malignancy as the reason of bleeding. The patient's hemodynamic status and the extent of liver bleeding are the most important factors to be taken into consideration in order to establish individualized management plan. Increased awareness of severe liver bleeding from amyloidosis may achieve reduced mortality of this potentially fatal complication.
\end{abstract}

Keywords: Amyloidosis, Spontaneous Liver Bleeding, Case, Review

\section{Introduction}

Amyloidosis is a group of haematological disorders caused by misfolding of extracellular proteins. In the extracellular matrix these proteins are organized as insoluble fibrils which can be found in most organs in the body [1]. The most common and serious form of amyloidosis is systemic immunoglobulin light chain (AL) amyloidosis, which is characterized by monoclonal immunoglobulin light chains associated with plasma cell dyscrasia [2-3]. Systemic AL amyloidosis may manifest with cardiac, kidney, neurological, soft tissue as well as gastrointestinal and hepatic involvement $[1,4]$. Structural changes in the liver and hepatic vessels in combination with a variety of coagulopathies may contribute to spontaneous liver rupture and bleeding in amyloidosis [1, 5-7]. Although hepatic involvement in amyloidosis is common, liver rupture or bleeding is a rare entity. Here we present a patient who suffers from systemic AL amyloidosis with cardiac, kidney, gastrointestinal and hepatic manifestations.

\section{Case Report}

A 62-year-old male with advanced AL-amyloidosis and known manifestations to the heart, liver and kidneys, presented to the emergency department (Karolinska University Hospital, Stockholm) due to onset of pain and discomfort in the right upper abdominal quadrant. During the clinical examination no signs of abdominal tenderness or distension were noticed and after the administration of NSAID the patient was evaluated as pain free. The biochemical samples revealed no signs of anemia, infection or liver disorder (WBC 9X10 6 , CRP 2, gglutamyl transferase $3.2 \mu \mathrm{kat} / \mathrm{L}$, aspartate aminotransferase $0.53 \mu \mathrm{kat} / \mathrm{L}$, alkaline phosphatase $1.3 \mu \mathrm{kat} / \mathrm{L}$ and albumin 42 $\mathrm{g} / \mathrm{L})$. PT, APTT and total bilirubin were normal. He was sent home with a referral to the radiology department for an outpatient ultrasound (US) examination because of high 
suspicion of gallbladder lithiasis. The US examination revealed a large subcapsular hematoma of about $12 \mathrm{~cm}$ in the lateral aspect of the right hemiliver, low echogenic intrahepatic structures suspicious for coagulating and abnormal liver parenchyma around the hematoma.

Because of these findings and the suspicion of an acute liver bleeding the patient was admitted to the surgical clinic for observation. The same evening a computed tomography of the liver was performed and revealed a big subscapular liver hematoma without active extravasation and no obvious bleeding site. The liver parenchyma was infiltrated by amyloidosis and the radiologist recommended investigation with an extra radiological modality with magnetic resonance imaging (MRI) of the liver (Figure 1). No obvious signs of bleeding were noticed clinically and after one day's observation the patient was discharged home in stable condition, with a planned MRI. The subsequent MRI was performed after a week and revealed a $4,5 \mathrm{~cm}$ subcapsular hematoma without changes from the previous CT. No signs of focal liver anomalies, hepatocellular carcinoma (HCC) or other malignancies, was seen (Figure 2).

The case was discussed in a multidisciplinary conference which decided that no surgical intervention was needed, and active surveillance was recommended. The patient was informed about the plan and recommended to visit the emergency department if any signs of abdominal pain or discomfort from the abdomen occurred. After three months a follow-up liver US revealed a partial regress of the hematoma and after six months the clinical examination and biochemical samples of the patient showed no worrisome features.

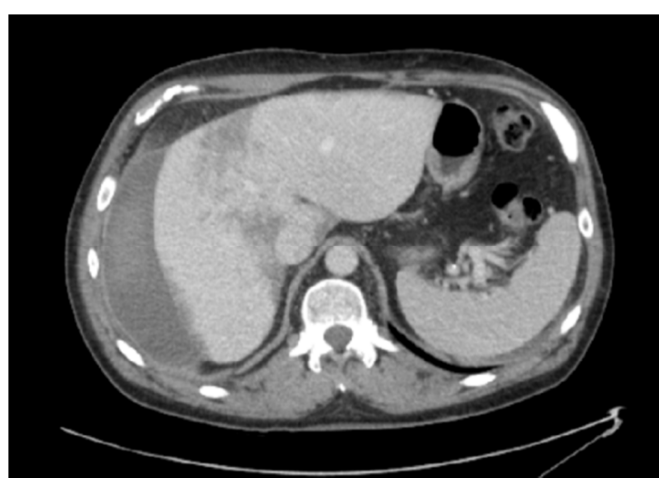

Figure 1. Representing subcapsular hematoma in CT scan.

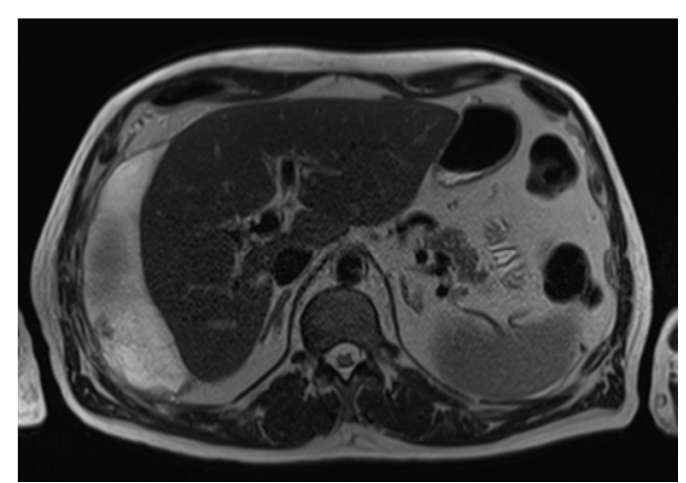

Figure 2. Representing subcapsular hematoma in MRI.

\section{Discussion}

Amyloidosis is a heterogeneous group of disorders defined by the misfolded fibril precursor protein. Amyloidosis can be divided into systemic and localized forms, with systemic forms accounting for $80-90 \%$ of all cases [8]. In systemic AL amyloidosis there is excessive production of immunoglobulin light chains as a result of plasma cell dysfunction. In approximately $15 \%$ of the cases the patient has multiple myeloma [1]. The incidence of systemic AL amyloidosis is estimated to 8 per million per year [3]. Other forms of amyloidosis include systemic AA amyloidosis which is secondary to infection, inflammation or neoplasia, $\beta 2 \mathrm{M}$ amyloidosis which occurs after years of dialysis, hereditary systemic amyloidosis which is caused by autosomal dominant mutation and senile systemic amyloidosis which is associated with the normal aging process [1]. Systemic AL amyloidosis is treated with chemotherapy regimens, while systemic AA amyloidosis is treated with therapies targeting the underlying inflammatory etiology. For hereditary systemic amyloidosis the definitive treatment is organ transplantation [1].

Hepatic involvement is seen in approximately $70 \%$ of patients with systemic AL amyloidosis, and is also present in other forms of amyloidosis. Hepatic amyloidosis is usually asymptomatic. When hepatic amyloidosis becomes symptomatic the patients often have involuntary weight loss, hepatomegaly, proteinuria and elevated serum alkaline phosphatase level [9]. Also C-reactive proterin and serum albumin are elevated in amyloidosis but the differences are less significant [4]. There are also some more rare complications associated with hepatic amyloidosis such as portal hypertension and cholestatic jaundice [10-12]. The differential diagnoses of hepatic amyloidosis include primary liver tumors and liver metastases [9]. Radiological tests of hepatic amyloidosis include ultrasonography, CT and MRI but are all unspecific [1, 13]. To confirm the diagnosis of amyloidosis histological analysis is required. The gold standard method is Congo red staining and amyloid deposits display green birefringence under cross-polarized light. Tissue biopsy is commonly obtained from rectum or abdominal fat due to low risk of complications [1]. Obtaining biopsies from a liver with amyloid involvement has been associated with increased risk of bleeding compared to a normal liver [4, 9].

Amyloid deposits can be found in liver parenchyma, liver stroma as well as liver vasculature [1]. The pathogenesis of liver rupture in amyloidosis is not fully understood. There are speculations that amyloid deposits make the liver capsule stiff and easier to break at the same time as the liver itself gets larger because of swelling or bleeding. In addition, amyloid deposits in the vessel walls may make the vessels fragile [6-7]. Moreover, deficiencies of coagulation factors, especially factor $\mathrm{X}$, as well as well hypofibrinogenemia may contribute to bleeding [5-6]. Previous studies suggest that the prothrombin time should be monitored in patients with primary hepatic amyloidosis as around $30 \%$ of these patients may have prolonged prothrombin time resulting in increased 
risk of bleeding [5, 9].

Liver rupture with severe liver bleeding in patients with amyloidosis is a rare and potentially fatal complication. Other conditions associated with spontaneous liver rupture include large hepatocellular carcinoma, preeclampsia and malaria [6]. By literature search we have found 18 cases of hepatic rupture and haemorrhage in association with amyloidosis as listed below. Only cases with available abstracts in English are presented. In about a third of the cases the diagnosis of amyloidosis is established after the patients present with acute liver rupture and hematoma. Involuntary weight loss and hepatomegaly are the two most common symptoms if the patient presents any symptoms at all. Some patients may have a previous history of hemorrhages or hematomas since coagulation defect is associated with amyloidosis. The presence of proteinuria in combination with elevated serum alkaline phosphatase level should lead to the suspicion of hepatic amyloidosis.

Traditionally emergency laparotomy with packing and sometimes hepatic artery ligation has been performed in the event of liver rupture, although transarterial embolization has become an emerging treatment option during the recent decade. In a case report Lehmann et al suggest transarterial embolization to be first choice to manage spontaneous liver rupture [7]. In six of the cases laparotomy was carried out with mixed outcomes, four cases resulting in death and two cases resulting in recovery. Transarterial embolization was performed in six cases, in four of them the patients were treated successfully and in two of them the patients deceased. Notably, in the case reported by Lehmann et al in which laparotomy was performed followed by transarterial embolization, the clinical course resulting in death was complicated by wound infection and necrosis. Emergency liver transplantation was carried out for two younger patients with hereditary lysozyme systemic amyloidosis and both of them recovered postoperatively. We only found one case in which the patient was successfully managed with conservative treatment alone and our case is the second reported case with liver hematoma treated conservatively. It is worth mentioning that the patient we present had only mild clinical symptoms from his liver hematoma without any signs of circulatory failure. The choice of management should be individualized. The patient's hemodynamic status and extent of liver bleeding are particularly important factors to be taken into consideration. Moreover, we think that it is crucial to exclude underlying malignancy in patients with liver bleeding, even those with known diagnosis of amyloidosis. Also, the patients should be carefully informed with the risk of re-bleeding and should be aware of such symptoms.

\section{Conclusions.}

Liver rupture with severe liver bleeding in patients with amyloidosis is a rare and potentially fatal complication. Traditionally emergency laparotomy and hepatic artery ligation has been performed in the event of liver rupture, although transarterial embolization has become an emerging treatment option during the recent decade. Emergency liver transplantation has been performed in cases of younger patients with notable results. In rare cases conservative treatment can be the treatment option in patients with mild clinical symptoms and no signs of circulatory failure. The choice of management should be individualized and the patient's hemodynamic status and extent of liver bleeding are important factors to be taken into consideration. In all patients it is crucial to exclude underlying malignancy as the reason of bleeding.

Table 1. Previously published cases of liver rupture and/or bleeding in patients with amyloidosis.

\begin{tabular}{|c|c|c|c|c|c|c|}
\hline Study & Patient & $\begin{array}{l}\text { Known } \\
\text { amyloidosis }\end{array}$ & Type of amyloidosis & Clinical manifestation & Intervention & Outcome \\
\hline $\begin{array}{l}\text { Röllinghoff et } \\
\text { al, } 1976(14)\end{array}$ & 37 yo female & Yes & Systemic AL & Intrahepatic haemorrhage & Unknown & Death \\
\hline $\begin{array}{l}\text { Hurd et al, } 1980 \\
\text { (15) }\end{array}$ & 45 yo female & Yes & Systemic AL & Bilobar subcapsular hematomas & Laparotomy with packing & Death \\
\hline $\begin{array}{l}\text { Levy-Lahad E } \\
\text { et al, } 1986(16)\end{array}$ & 57 yo male & Yes & $\begin{array}{l}\text { Systemic AL and small- } \\
\text { cell lymphoma }\end{array}$ & Subcaspsular liver hematoma & $\begin{array}{l}\text { Conservative treatment with } \\
\text { blood products }\end{array}$ & $\begin{array}{l}\text { Resolving } \\
\text { hematoma }\end{array}$ \\
\hline $\begin{array}{l}\text { Ades et al, } 1989 \\
\text { (17) }\end{array}$ & 46 yo female & No & Systemic AL & $\begin{array}{l}\text { Subcapsular and extracapsular } \\
\text { liver hematomas }\end{array}$ & $\begin{array}{l}\text { Laparotomies with ligation of } \\
\text { hepatic artery and packing }\end{array}$ & Death \\
\hline $\begin{array}{l}\text { Harrison et al, } \\
1996 \text { (18) }\end{array}$ & 15 yo male & Yes & $\begin{array}{l}\text { Hereditary lysozyme } \\
\text { systemic amyloidosis }\end{array}$ & $\begin{array}{l}\text { Subcapsular and extracapsular } \\
\text { liver hematomas }\end{array}$ & $\begin{array}{l}\text { Emergency liver } \\
\text { transplantation }\end{array}$ & Recovery \\
\hline $\begin{array}{l}\text { Ooi et al, } 1996 \\
\text { (19) }\end{array}$ & 41 yo male & No & Systemic AL & $\begin{array}{l}\text { Liver rupture with intraperitoneal } \\
\text { bleeding }\end{array}$ & Laparotomies with packing & Recovery \\
\hline $\begin{array}{l}\text { Satue et al, } \\
1996(20)\end{array}$ & 32 yo female & Yes & $\begin{array}{l}\text { AA amyloidosis } \\
\text { secondary to } \\
\text { Mediterranean fever } \\
\text { with renal failure }\end{array}$ & $\begin{array}{l}\text { Liver rupture with intraperitoneal } \\
\text { bleeding }\end{array}$ & Resuscitation & Death \\
\hline $\begin{array}{l}\text { Bujanda et al, } \\
1997(21)\end{array}$ & 59 yo male & Unknown & Unknown & $\begin{array}{l}\text { Liver rupture with subcapsular } \\
\text { hematoma }\end{array}$ & Laparotomy & $\begin{array}{l}\text { Intraoperative } \\
\text { death }\end{array}$ \\
\hline $\begin{array}{l}\text { Kacem et al, } \\
1998(22)\end{array}$ & 46 yo male & No & Systemic AL & $\begin{array}{l}\text { Recurrent subcapsular liver } \\
\text { hematomas }\end{array}$ & $\begin{array}{l}\text { First time laparotomy with } \\
\text { local coagulation, second time } \\
\text { conservative treatment }\end{array}$ & Recovery \\
\hline $\begin{array}{l}\text { Mukhopadhya } \\
\text { et al, } 2004(23)\end{array}$ & 48 yo male & Yes & $\begin{array}{l}\text { Systemic AL and } \\
\text { multiple myeloma }\end{array}$ & $\begin{array}{l}\text { Intraperitoneal haemorrhage with } \\
\text { rupture of the right lobe }\end{array}$ & Transarterial embolization & Recovery \\
\hline Loss et al, 2006 & 34 yo female & No & Hereditary lysozyme & Liver rupture with intraperitoneal & Emergency liver & Recovery \\
\hline
\end{tabular}




\begin{tabular}{|c|c|c|c|c|c|c|}
\hline Study & Patient & $\begin{array}{l}\text { Known } \\
\text { amyloidosis }\end{array}$ & Type of amyloidosis & Clinical manifestation & Intervention & Outcome \\
\hline (6) & & & systemic amyloidosis & hematoma & transplantation & \\
\hline $\begin{array}{l}\text { Naito et al, } \\
2009 \text { (24) }\end{array}$ & 42 yo male & Yes & Systemic AL & $\begin{array}{l}\text { Subcapsular hematoma in the } \\
\text { right lobe }\end{array}$ & Transarterial emobolization & Recovery \\
\hline $\begin{array}{l}\text { Tam et al, } 2009 \\
(25)\end{array}$ & 55 yo female & No & Systemic AL & $\begin{array}{l}\text { Recurrent subcapsular } \\
\text { hematomas }\end{array}$ & $\begin{array}{l}\text { First time exploratory } \\
\text { laparoscopy followed by } \\
\text { conservative treatment, second } \\
\text { time conservative treatment }\end{array}$ & Death \\
\hline $\begin{array}{l}\text { Lehmann et al, } \\
2012 \text { (7) }\end{array}$ & 81 yo male & No & Systemic AL & $\begin{array}{l}\text { Large confluent subcapsular } \\
\text { hematoma and rupture of both } \\
\text { liver lobes }\end{array}$ & $\begin{array}{l}\text { Laparotomy followed by } \\
\text { transarterial embolization }\end{array}$ & Death \\
\hline $\begin{array}{l}\text { Szturz et al, } \\
2013(26)\end{array}$ & Female & No & Systemic AL & $\begin{array}{l}\text { Recurrent intraperitoneal } \\
\text { haemorrhage }\end{array}$ & $\begin{array}{l}\text { Repeated surgical revision not } \\
\text { specified }\end{array}$ & Death \\
\hline $\begin{array}{l}\text { Mousa et al, } \\
2014(27)\end{array}$ & 50 yo male & Yes & $\begin{array}{l}\text { Systemic AL and } \\
\text { multiple myeloma }\end{array}$ & $\begin{array}{l}\text { Intraperitoneal haemorrhage with } \\
\text { rupture of the left lobe }\end{array}$ & Transarterial embolization & Recovery \\
\hline $\begin{array}{l}\text { Suda et al, } 2017 \\
\text { (28) }\end{array}$ & 79 yo male & Yes & Systemic AL & Intraperitoneal haemorrhage & Transarterial embolization & Death \\
\hline $\begin{array}{l}\text { Lohana et al, } \\
2019(29)\end{array}$ & $\begin{array}{l}44 \text { yo } \\
\text { female }\end{array}$ & No & Systemic AL & Intrahepatic haemorrhage & Transarterial embolization & Recovery \\
\hline
\end{tabular}

\section{References}

[1] Syed U, Ching Companioni RA, Alkhawam H, Walfish A. Amyloidosis of the gastrointestinal tract and the liver: clinical context, diagnosis and management. Eur $\mathrm{J}$ Gastroenterol Hepatol. 2016; 28 (10): 1109-21.

[2] Mahmood S, Bridoux F, Venner CP, Sachchithanantham S, Gilbertson JA, Rowczenio D, et al. Natural history and outcomes in localised immunoglobulin light-chain amyloidosis: a long-term observational study. Lancet Haematol. 2015; 2 (6): e241-50.

[3] Madsen LG, Gimsing P, Schiødt FV. Primary (AL) amyloidosis with gastrointestinal involvement. Scand J Gastroenterol. 2009; 44 (6): 708-11.

[4] Gertz MA, Kyle RA. Hepatic amyloidosis: clinical appraisal in 77 patients. Hepatology. 1997; 25 (1): 118-21.

[5] Mumford AD, O'Donnell J, Gillmore JD, Manning RA, Hawkins PN, Laffan M. Bleeding symptoms and coagulation abnormalities in 337 patients with AL-amyloidosis. Br J Haematol. 2000; 110 (2): 454-60.

[6] Loss M, Ng WS, Karim RZ, Strasser SI, Koorey DJ, Gallagher PJ, et al. Hereditary lysozyme amyloidosis: spontaneous hepatic rupture (15 years apart) in mother and daughter. role of emergency liver transplantation. Liver Transpl. 2006; 12 (7): 1152-5.

[7] Lehmann TG, Scheble V, Miller S, Heininger A, Fend F, Koenigsrainer A. Spontaneous hepatic rupture in amyloidosis - report of a case. Z Gastroenterol. 2012; 50 (12): 1296-301.

[8] Scott PP, Scott WW, Siegelman SS. Amyloidosis: an overview. Semin Roentgenol. 1986; 21 (2): 103-12.

[9] Park MA, Mueller PS, Kyle RA, Larson DR, Plevak MF, Gertz MA. Primary (AL) hepatic amyloidosis: clinical features and natural history in 98 patients. Medicine (Baltimore). 2003; 82 (5): 291-8.

[10] Serra L, Poppi MC, Criscuolo M, Zandomeneghi R. Primary systemic amyloidosis with giant hepatomegaly and portal hypertension: a case report and a review of the literature. Ital $\mathbf{J}$
Gastroenterol. 1993; 25 (8): 435-8.

[11] Zeijen RN, Sels JP, Flendrig JA, Arends JW. Portal hypertension and intrahepatic cholestasis in hepatic amyloidosis. Neth J Med. 1991; 38 (5-6): 257-61.

[12] Peters RA, Koukoulis G, Gimson A, Portmann B, Westaby D, Williams R. Primary amyloidosis and severe intrahepatic cholestatic jaundice. Gut. 1994; 35 (9): 1322-5.

[13] Kim SH, Han JK, Lee KH, Won HJ, Kim KW, Kim JS, et al. Abdominal amyloidosis: spectrum of radiological findings. Clin Radiol. 2003; 58 (8): 610-20.

[14] Röllinghoff W, Braun HJ, Schad FJ. [Primary amyloidosis presenting as intrahepatic cholestasis (author's transl)]. Dtsch Med Wochenschr. 1976; 101 (50): 1838-41.

[15] Hurd WW, Katholi RE. Acquired functional asplenia. Association with spontaneous rupture of the spleen and fatal spontaneous rupture of the liver in amyloidosis. Arch Intern Med. 1980; 140 (6): 844-5.

[16] Levy-Lahad E, Steiner-Salz D, Berkman N, Chisin R, Levensart P, Leitersdorf E. Reversible functional asplenia and subcapsular liver hematoma--two distinctive manifestations of amyloidosis. Klin Wochenschr. 1987; 65 (22): 1104-7.

[17] Ades CJ, Strutton GM, Walker NI, Furnival CM, Whiting G. Spontaneous rupture of the liver associated with amyloidosis. J Clin Gastroenterol. 1989; 11 (1): 85-7.

[18] Harrison RF, Hawkins PN, Roche WR, MacMahon RF, Hubscher SG, Buckels JA. 'Fragile' liver and massive hepatic haemorrhage due to hereditary amyloidosis. Gut. 1996; 38 (1): $151-2$.

[19] Ooi LL, Lynch SV, Graham DA, Strong RW. Spontaneous liver rupture in amyloidosis. Surgery. 1996; 120 (1): 117-9.

[20] Satue JA, Ortuño T, Carabias E, Cisneros C, Araque A, Fernandez Zatarain G, et al. Fatal spontaneous liver rupture in a renal transplant patient with amyloidosis. Nephron. 1996; 73 (2): 355-6.

[21] Bujanda L, Beguiristain A, Alberdi F, Cosme A, Ruíz de la Hermosa J, Gutiérrez-Stampa, et al. Spontaneous rupture of the liver in amyloidosis. Am J Gastroenterol. 1997; 92 (8): 1385-6. 
[22] Kacem C, Helali K, Puisieux F. Recurrent spontaneous hepatic rupture in primary hepatic amyloidosis. Ann Intern Med. 1998; 129 (4): 339.

[23] Mukhopadhya A, Raghuram L, Justus A, Joseph AJ, Eapen CE, Chandy GM. Transcatheter hepatic artery embolization for spontaneous rupture of amyloid liver. Indian $\mathrm{J}$ Gastroenterol. 2004; 23 (1): 26-7.

[24] Naito KS, Ichiyama T, Kawakami S, Kadoya M, Tabata T, Matsuda M, et al. AL amyloidosis with spontaneous hepatic rupture: successful treatment by transcatheter hepatic artery embolization. Amyloid. 2008; 15 (2): 137-9.

[25] Tam M, Seldin DC, Forbes BM, Connors LH, Skinner M, Oran B, et al. Spontaneous rupture of the liver in a patient with systemic AL amyloidosis undergoing treatment with high-dose melphalan and autologous stem cell transplantation: a case report with literature review. Amyloid. 2009; 16 (2): 103-7.
[26] Szturz P, Kyclová J, Moulis M, Navrátil M, Adam Z, Vaníček $\mathrm{J}$, et al. Extensive $\mathrm{Al}$ amyloidosis presenting with recurrent liver hemorrhage and hemoperitoneum: case report and literature review. Klin Onkol. 2013; 26 (1): 49-52.

[27] Mousa AY, Abu-Halimah S, Alhalbouni S, Hass SM, Yang C, Gill G, et al. Amyloidosis and spontaneous hepatic bleeding, transcatheter therapy for hepatic parenchymal bleeding with massive intraperitoneal hemorrhage: a case report and review of the literature. Vascular. 2014; 22 (5): 356-60.

[28] Suda T, Oguri H. A case of primary amyloidosis with spontaneous hepatic rupture. Nihon Shokakibyo Gakkai Zasshi. 2017; 114 (6): 1039-45.

[29] Lohana AK, Abid S, Sayani R, Tahir U, Shaikh PA. Hepatobiliary and Pancreatic: Bleeding in amyloid liver: A rare presentation of primary liver amyloidosis. J Gastroenterol Hepatol. 2019. 